\title{
34. STABLE ISOTOPIC, ASSEMBLAGE, AND PALEOENVIRONMENTAL INVESTIGATIONS OF JUVENILE-OCEAN SEDIMENTS RECOVERED ON LEG 122, WOMBAT PLATEAU, NORTHWEST AUSTRALIA ${ }^{1}$
}

\author{
Timothy J. Bralower ${ }^{2}$
}

\begin{abstract}
A sedimentary sequence documenting the early history of the proto-Indian Ocean was drilled at Site 761 on the Wombat Plateau, northwest Australia. Directly above the post-rift unconformity, two lithologic units were recovered which reflect deposition in incipient oceanic environments. The lower unit, composed of sandstone, contains abundant belemnites and a few lenses composed of low-diversity coccolith assemblages. The second unit, composed of chalk, contains abundant calcispheres, thoracospheres, low-diversity coccolith assemblages, and a few radiolarians. Belemnites and organisms that produced calcispheres and thoracospheres are thought to be opportunistic. Their abundance, and the absence of a normal marine fauna and flora, reflects an unstable early ocean environment. Stable oxygen and carbon isotopic data for the two units fall into almost separate fields. Heavy $\delta^{18} \mathrm{O}$ values for the belemnites indicate that they have not been affected by recrystallization. Instead, these isotopic values are thought to indicate either the deep, cool habitat of the belemnites or strong vital effects.

A bulk chalk $\delta^{18} \mathrm{O}$ value from the belemnite sand is 3 to 4 parts per mil lighter than the belemnite $\delta^{18} \mathrm{O}$ values, possibly because it is largely composed of coccoliths which inhabited warmer surface waters. Light $\delta^{13} \mathrm{C}$ values for bulk calcisphere-bearing nannofossil chalk samples are thought to be a direct result of upwelling or of vital effects. Heavy $\delta^{18} \mathrm{O}$ values for the chalk unit are interpreted as resulting from upwelling of cool waters. Assemblage and isotopic data are consistent with this incipient ocean basin being highly productive, either as a result of upwelling or runoff of nutrient-rich waters from nearby land areas. However, it is not possible to rule out the control of vital effects on the isotopic signature of any of the fossil groups.
\end{abstract}

\section{INTRODUCTION}

A major objective of several recent Deep Sea Drilling Project (DSDP) and Ocean Drilling Program (ODP) legs has been to study rifting processes and the associated development of passive continental margins. Leg 122 had a similar goal: to investigate the early history of the Tethyan/Indian Ocean Basin through pre-rift, syn-rift, and post-rift stages by detailed drilling on its southern margin, the Exmouth Plateau, northwest Australia. This was viewed as an ideal continental margin to study as it is old and relatively sediment-starved. During the course of Leg 122, a total of six sites were drilled, two on the central Exmouth Plateau and a transect of four on the Wombat Plateau, a small subsidiary horst to the northeast (Fig. 1). At Site 761, located in the middle of the Wombat Plateau, the most complete section was recovered that allowed a detailed reconstruction of the early rifting history of this margin.

Stratigraphic and sedimentologic investigations of Site 761 reveal a thick, Upper Triassic, pre-rift sequence of marine and non-marine sediments (Fig. 2). This is overlain by an unconformity that spans the Jurassic and represents a syn-rift phase of erosion and nondeposition. The section directly above the post-rift unconformity consists of hemipelagic and pelagic sediments deposited in the incipient ocean basin (Fig. 2). This chapter focuses on two Lower Cretaceous lithologic units, deposited immediately above the post-rift unconformity, that

\footnotetext{
${ }^{1}$ von Rad, U., Haq, B. U., et al., 1992. Proc. ODP, Sci. Results, 122: College Station, TX (Ocean Drilling Program).

${ }^{2}$ Department of Geology, Florida International University, University Park, Miami, FL 33199, U.S.A. (Current address: Department of Geology, University of North Carolina, Chapel Hill, NC 27599-3315, U.S.A.)
}

contain faunal and floral evidence of deposition in a restricted, juvenile ocean basin.

The lithologies investigated contain four major fossil groups: belemnites, calcispheres, thoracospheres, and coccoliths. Calcispheres are thought to represent resting cysts which are produced by calcareous dinoflagellates under adverse conditions (Keupp, 1979). Living Thoracosphaera heimii is a dinoflagellate which produces a calcareous skeleton during the vegetative motile stage (Tangen et al., 1982) and therefore has a different taxonomic affinity to the calcispheres. It is unclear whether ancient thoracospheres are related to the calcispheres or to $T$. heimii, as all of these taxa possess a similar wall structure and an aperture with an operculum. The calcispheres and thoracospheres are divided here based on their appearance in the light microscope.

The paleoecologic affinities of the faunal and floral elements investigated are not always clear; however, their diversity and distribution provide useful paleoenvironmental information. Similar information can be obtained independently based on the stable isotopic signature of shell material. Stable isotopes of carbon and oxygen in aragonitic and calcitic fossils have been utilized in determining paleosalinity (e.g., Dodd and Stanton, 1975). Average fresh water shows a distinctly lighter carbon isotopic signature compared with marine water because it inherits a highly negative signal from the soil carbon reservoir (e.g., Hudson, 1977). Oxygen isotopic values of fresh waters are usually also lighter than those of marine waters as a result of their lowered salinity. These trends are complicated by the effects of changing temperature (e.g., Anderson and Arthur, 1983) and assemblage composition (e.g., Dudley et al., 1986) on bulk stable isotope analyses of fine-grained marine carbonates. Several authors (e.g., Dudley and Goodney, 1979; Anderson and Steinmetz, 1981; Paull and Thierstein, 1987) have illustrated the strong vital effects pres- 


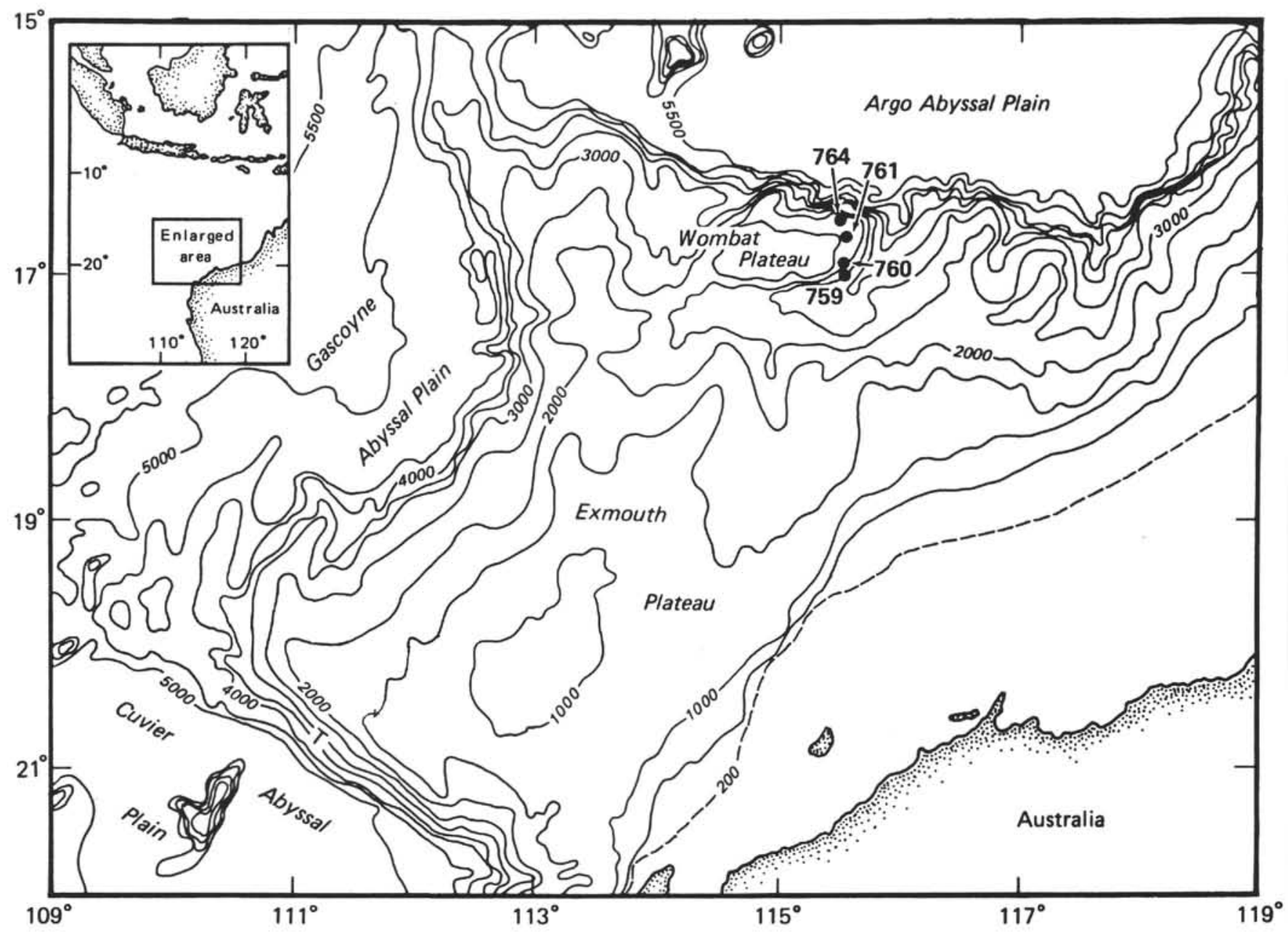

Figure 1. Location of Site 761 on the Wombat Plateau off northwest Australia.

ent in stable isotopic analyses of nannoplankton. As a result of these complications, isotopic data cannot be used to determine absolute paleosalinity, but rather to interpret broad trends such as mixing of fresh and marine waters (e.g., Geary et al., 1989). In this investigation, faunal and floral assemblage studies are combined with stable isotope analyses of individual fossil particles and bulk samples in order to reconstruct the paleoceanography of incipient Neo-Tethys.

\section{STRATIGRAPHY AND SEDIMENTOLOGY}

Site 761 is situated on the Wombat Plateau $\left(16.74^{\circ} \mathrm{S}\right.$, $115.54^{\circ} \mathrm{E}$ ) at a water depth of $2168 \mathrm{~m}$. Two holes were drilled. In Hole 761B, $286 \mathrm{~m}$ of sediment were penetrated, and $199 \mathrm{~m}$ were recovered; in Hole $761 \mathrm{C}, 437 \mathrm{~m}$ of sediment were penetrated, and $72 \mathrm{~m}$ were recovered. The upper part of the sedimentary column at this site consists of calcareous ooze and chalk of Quaternary to Albian age. These sediments contain diverse assemblages of nannofossils and foraminifers which indicate deposition in hemipelagic and pelagic environments. Beneath them are two separate units deposited in juvenile-ocean conditions (Fig. 3). The upper unit consists of light to dark yellowish brown calcisphere nannofossil chalk with several discrete bentonite layers (Pl. 1). Floral assemblages in this unit are of low diversity and the relative proportion of coccoliths, thoracospheres, and calcispheres vary significantly. The lower unit is composed of yellowish brown to dark brown ferruginous sandstone (PI. 2). This unit contains numerous belemnite guards as well as thin lenses enriched in coccoliths. More detailed descriptions of both units are given in Haq, von Rad, O'Connell, et al. (1990) and von Rad and Thurow (this volume).

The two units of interest were recovered in both Holes $761 \mathrm{~B}$ and $761 \mathrm{C}$, but recovery from the latter hole was more complete and was used in this investigation. A total of $7.3 \mathrm{~m}$ of calcisphere nannofossil chalk was recovered from $15.4 \mathrm{~m}$ penetrated and a total of $1.05 \mathrm{~m}$ of belemnite sandstone was recovered from $4.1 \mathrm{~m}$ penetrated in Hole $761 \mathrm{C}$.

\section{TECHNIQUES}

Smear slides of 50 samples from the two units were prepared and described. Proportions of various fossil particles and inorganic carbonate were estimated semiquantitatively by visual inspection in the light microscope (LM). Bulk samples were selected for stable isotopic analysis and an additional smear slide was prepared from each aliquot. In one sample $(122-761 \mathrm{C}-7 \mathrm{R}-1,145-146 \mathrm{~cm})$ the calcisphere fraction was enriched by repeated centrifuging, increasing the relative proportion of these particles from $50 \%$ to $90 \%$ of the fine $(<38$ $\mu \mathrm{m})$ fraction. Stable isotopic analyses were also carried out on three belemnite rostra. Each part was studied in the scanning electron microscope (SEM) so that its detailed texture could be observed. A fine drill was then used to subsample these three parts in different places so that the effect of recrystallization on isotopic trends could be evaluated. Samples of $\mathrm{CO}_{2}$ 


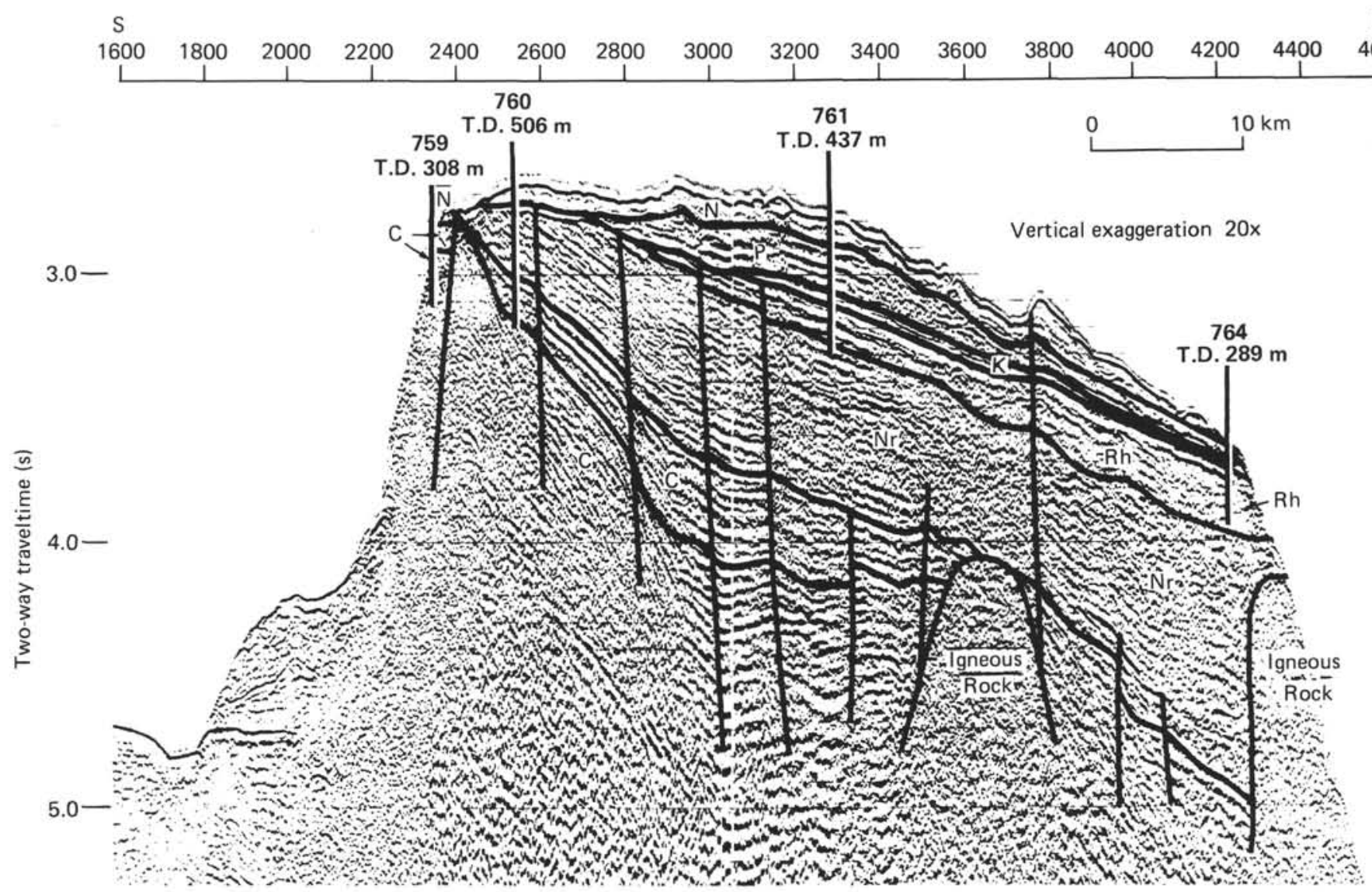

Figure 2. North-south seismic stratigraphic section through the Wombat Plateau indicating location of Sites 759, 760, 761, and 764 and approximate section recovered at each. $\mathrm{N}=$ Neogene, $\mathrm{P}=$ Paleogene, $\mathrm{K}=$ Cretaceous, $\mathrm{Rh}=\mathrm{Rhaetian}, \mathrm{Nr}=\mathrm{Norian}$, and $\mathrm{C}=\mathrm{Carnian}$.

were extracted from the carbonate using reaction with phosphoric acid at $90^{\circ} \mathrm{C}$ in a common acid bath. Ratios of ${ }^{13} \mathrm{C} /{ }^{12} \mathrm{C}$ and ${ }^{18} \mathrm{O} /{ }^{16} \mathrm{O}$ were determined using a Finnigan-MAT 251 Mass Spectrometer in the laboratory of Dr. P. Swart at the Rosenstiel School of Marine and Atmospheric Sciences, University of Miami, by correcting ratios of mass $45 / 44$ and $46 / 44$ for appropriate inter-references after a method modified for a triple collector instrument from Craig (1957). All data are reported in per mil (\%o) deviations from PDB. The external precision (1 sigma) for this method as determined by processing 20 consecutive samples is 0.026 for $\delta^{18} \mathrm{O}$ and 0.016 for $\delta^{13} \mathrm{C}$. Scanning electron microscopy was performed on an ISIDS130 SEM also at the University of Miami.

\section{RESULTS}

\section{Assemblage Composition}

The two units investigated have very different faunal and floral assemblages. The calcisphere nannofossil chalk is composed of varying proportions of calcispheres, coccoliths, thoracospheres, and radiolarians whereas the sandstone contains belemnites and coccoliths (Table 1).

As indicated previously, I differentiate between calcispheres (Pl. 3, Figs. 8, 9) and thoracospheres (Pl. 5, Fig. 3) based on their LM properties even though this division may have no taxonomic significance. Optically these particles are different, however, and therefore this distinction is maintained. Calcispheres appear to be thicker walled but more translucent, producing a birefringent, circular outline and a powerful pseudoextinction cross in cross-polarized light (Pl. 3, Figs. 8,9). Individual elements of thoracospheres are more visible, producing a characteristic intricate pattern in crosspolarized light (PI. 5, Fig. 3). These particles (average diameter $10-15 \mu \mathrm{m}$ ) tend to be smaller than calcispheres (average diameter 20-50 $\mu \mathrm{m}$ ) in the material examined and more commonly occur as fragments. Estimating the relative abundance of fine-fraction $(<38 \mu \mathrm{m})$ particles in terms of mass contribution is extremely difficult. The data presented (Table 1) represent numbers of discrete carbonate particles and not volume of carbonate. This is significant because thoracospheres have 10,000 times the mass of an individual small coccolith (Paull et al., 1988) (e.g., Pl. 3, Fig. 6). In addition, many of the non-coccolith particles, especially the thoracospheres, are often broken into smaller fragments or individual elements. Thus the relative abundances given are not accurate, but they are internally consistent so that differences between samples can be determined.

Because of the extensive fragmentation of both calcispheres and thoracospheres, it was difficult to analyze the composition of assemblages in the calcisphere nannofossil chalk. However, SEM analysis of calcispheres and LM analysis of thoracospheres indicate that assemblages of both are of very low diversity. In the case of the thoracospheres, assemblages appear to be monospecific, composed of Thoracosphaera operculata. The calcisphere taxa, are mostly Orthopithonella cf. deflandrei (e.g., Pl. 4) with a few Obliquipithonella multistrata (e.g., Pl. 3, Fig. 1) (H. Keupp, pers. comm., 1990). Most calcispheres observed have an overgrown layer of 


\section{LITHOSTRATIGRAPHY}
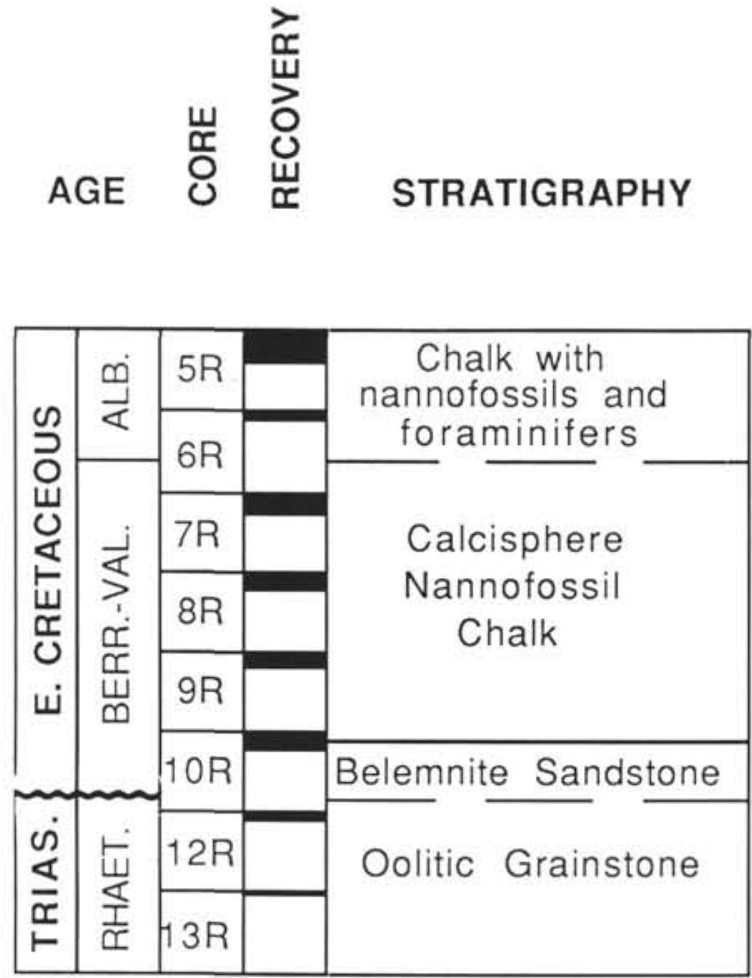

KEY:

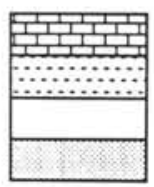

\section{CHALK}

BENTONITIC CLAYSTONE

SANDY SILTY CLAYSTONE

CLAYEY SANDSTONE
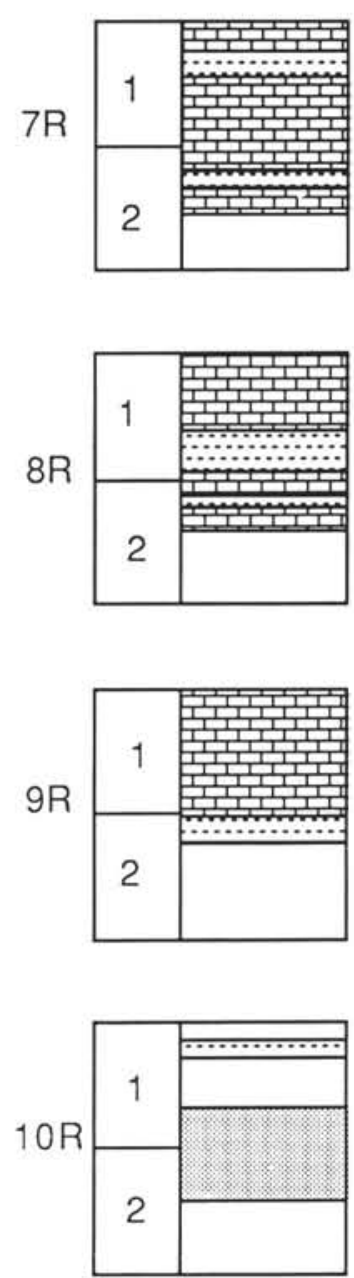

Figure 3. Lithostratigraphy, age, and core recovery of calcisphere nannofossil chalk and belemnite sandstone at Site 761 .

neomorphic calcite. A more detailed analysis of the diversity of the calcisphere assemblages in these samples is given by Keupp (this volume).

Coccolith assemblages in the calcisphere nannofossil chalk are of variable but generally low diversity (see Bralower and Siesser, this volume, for complete details). The dominant species in all samples is Watznaueria barnesae, a solutionresistant taxon. Several samples appear to be almost monospecific; however, this does not appear to be completely related to preservation because some of them are moderately well preserved. In other samples the diversity is moderate and $W$. barnesae is joined by a few Watznaueria ovata, Cretarhabdus sp., Crucibiscutum salebrosum, and Parhabdolithus embergeri, and rare Watznaueria communis, W. britannica, Cyclagelosphaera deflandrei, C. margerelii, Ethmorhabdus hauterivianus, Assipetra infracretacea, Biscutum constans, Diazomatolithus lehmanii, Microstaurus chiastius, Speetonia colligata, Grantarhabdus meddii, Parhabdolithus asper, Conusphaera mexicana subsp. mexicana, and Rhagodiscus nebulosus. The latter species indicates a late Berriasian to early Valanginian age (Bralower et al., 1989).

Radiolarians were observed in several samples, but are far less common than the other microfossil groups. Two forms were noted (Pl. 5, Figs. 4-6) and are composed of silica based on energy dispersive spectrophotometric (EDS) analysis. One species has been identified as Cryptamphorella conara (Foreman) (C. Blome, pers. comm., 1990). This taxon has previously been assigned an Albian-Maestrichtian range (Sanfilippo and Riedel, 1985) which may be extended based on this investigation.

The belemnite-bearing sandstone unit contains no thoracospheres, calcispheres, or radiolarians. Coccoliths in this unit are generally less abundant and not as well preserved as in the overlying calcisphere nannofossil chalk. Diversity is low and assemblages are composed predominantly of Watznaueria barnesae with rare Cyclagelosphaera deflandrei, $C$. margerelii, W. ovata, Cretarhabdus sp., and Parhabdolithus embergeri. A similar age is assumed for this unit as the calcisphere nannofossil chalk based on the lithologic transition between them. This age is supported by preliminary belemnite biostratigraphy (Mutterlose, in press).

\section{Stable Isotopic Data}

The results of the carbon and oxygen isotopic analyses of bulk samples and belemnites are compiled in Table 2 and plotted in Figure $4 \mathrm{~A}$ and $4 \mathrm{C}$. The belemnite values are 
Table 1. Numeric proportions of fine-fraction particles in analyzed bulk sediments.

\begin{tabular}{|c|c|c|c|c|}
\hline $\begin{array}{l}\text { Core, section, } \\
\text { interval }(\mathrm{cm})\end{array}$ & Calcisphere & Thoracosphere & Coccolith & Inorganic \\
\hline \multicolumn{5}{|l|}{$122-761 \mathrm{C}$ - } \\
\hline $7 R-1,31-34$ & 15 & 5 & 80 & - \\
\hline $7 \mathrm{R}-1,39-40$ & 10 & 5 & 85 & - \\
\hline 7R-1, 145-146 (Bulk) & 50 & 35 & 15 & - \\
\hline 7R-1, 145-146 (Calcisphere) & 90 & 10 & - & \\
\hline $7 R-2,41-42$ & 40 & 40 & 20 & - \\
\hline $8 R-1,30-31$ & 80 & 15 & 5 & - \\
\hline $8 R-1,86-87$ & 25 & 35 & 20 & 20 \\
\hline $8 R-2,21-23$ & 20 & 5 & 25 & 50 \\
\hline $8 R-2,26-27$ & 25 & - & 25 & 50 \\
\hline $8 R-2,51-53$ & 50 & 25 & 25 & - \\
\hline $9 \mathrm{R}-1,38-39$ & 30 & 10 & 60 & - \\
\hline $9 \mathrm{R}-1,76-77$ & 15 & 70 & 5 & 10 \\
\hline $9 \mathrm{R}-1,91-92$ & 10 & 85 & 5 & - \\
\hline $9 \mathrm{R}-1,99-100$ & 30 & 65 & 5 & - \\
\hline $9 \mathrm{R}-2,3-4$ & 40 & 20 & 40 & - \\
\hline $10 \mathrm{R}-1,75-76$ & 10 & 80 & 10 & - \\
\hline $10 \mathrm{R}-1,136-137$ & - & - & 100 & - \\
\hline $10 \mathrm{R}-2,22-23$ & - & - & $<1$ & 100 \\
\hline
\end{tabular}

Note: Dash $=$ not observed.

compared to measurements made on well-preserved Jurassic belemnites by Spaeth et al. (1971) in Figure 4B. In Figure 4D, all of the data obtained are compared to typical isotopic values of calcareous sediments and sedimentary rocks compiled by Hudson (1977). In general, the calcisphere nannofossil chalk and belemnite analyses fall into two separate fields. The $\delta^{18} \mathrm{O}$ values in the belemnite samples range between $0.90 \%$ and $1.79 \%$ (PDB) with one exception; $\delta^{13} \mathrm{C}$ values vary between $-0.20 \%$ and $1.34 \%$, with one exception (Fig. 4A). Two analyses of chalk lenses were conducted in the belemnite sandstone unit. The first (Sample 122-761C-10R-2, 22-23 cm) is composed largely of inorganic calcite that has a $\delta^{18} \mathrm{O}$ value of $1.66 \%$ and $\delta^{13} \mathrm{C}$ value of $1.44 \%$. The second (Sample $122-761 \mathrm{C}-10 \mathrm{R}-1,136-137 \mathrm{~cm}$ ) is composed predominantly of coccoliths, and has a $\delta^{18} \mathrm{O}$ of $-2.26 \%$ and $\delta^{13} \mathrm{C}$ of $-0.63 \%$ (Fig. 4A). The calcisphere nannofossil chalk is generally lighter than these belemnite sand chalk lens samples in $\delta^{13} \mathrm{C}(-1.36 \%$ to $-5.23 \%$ ) and has $\delta^{18} \mathrm{O}$ of 0.08 to $-1.15 \%$.

\section{DISCUSSION}

\section{Paleoecology}

Interpretation of assemblages of belemnites, coccoliths, thoracospheres, and calcispheres is hampered by the lack of information on the paleoecologic affinities of individual taxa. In the case of the calcispheres and thoracospheres, this problem is particularly acute because the taxonomic relationship of these fossils with living phytoplankton is uncertain. The calcispheres are thought to be calcareous resting cysts produced by certain dinoflagellates in adverse environments (Keupp, 1979). Possible living relatives of calcispheres, Peridinium troichoideum and Scrippsiella sweenyae are found commonly in continental margin settings and are known to have wide salinity, temperature, and nutrient tolerances (Wall et al., 1970).

Interpretation of the exact paleoecological significance of calcisphere abundance is difficult. Calcispheres have an open ocean and shelfal distribution in the geologic record. It has been proposed that the dinoflagellates that produced calcispheres responded to variations in salinity and productivity (Lins et al., 1977). These dinoflagellates are also thought to be opportunistic (Fischer and Arthur, 1977). For example, they
Table 2. Stable isotopic analyses of bulk sediments and belemnite rostra.

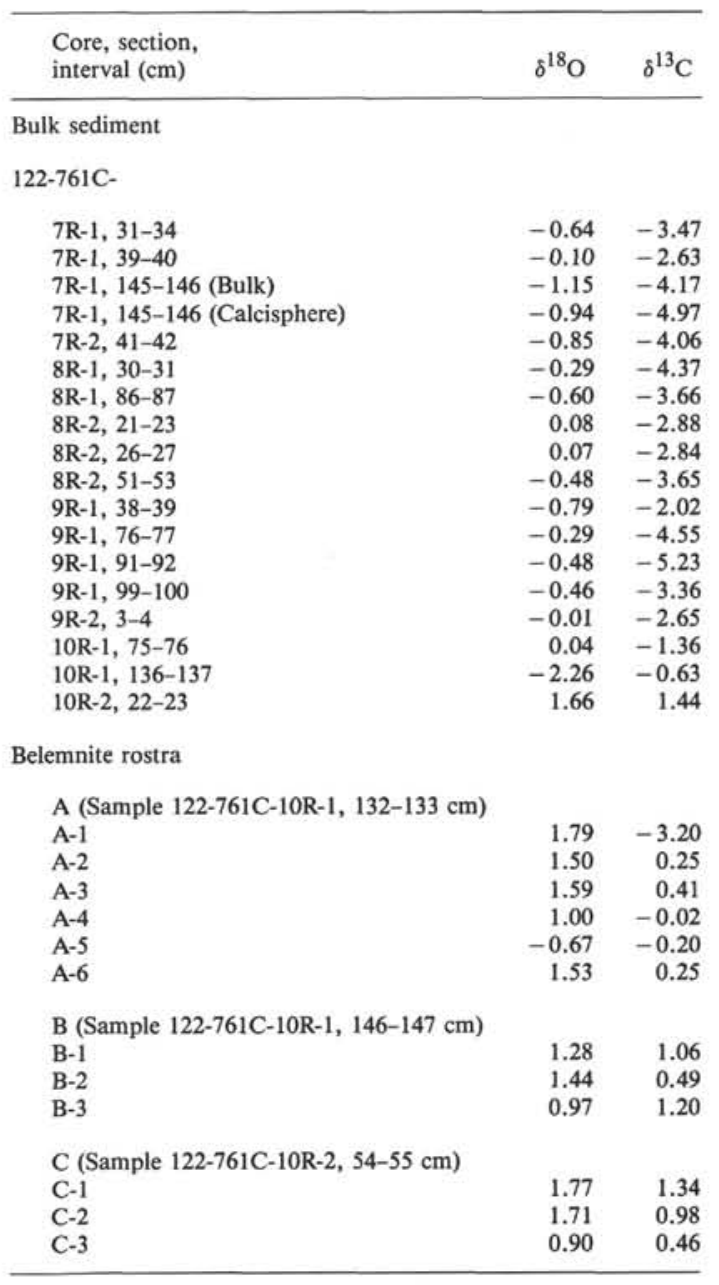



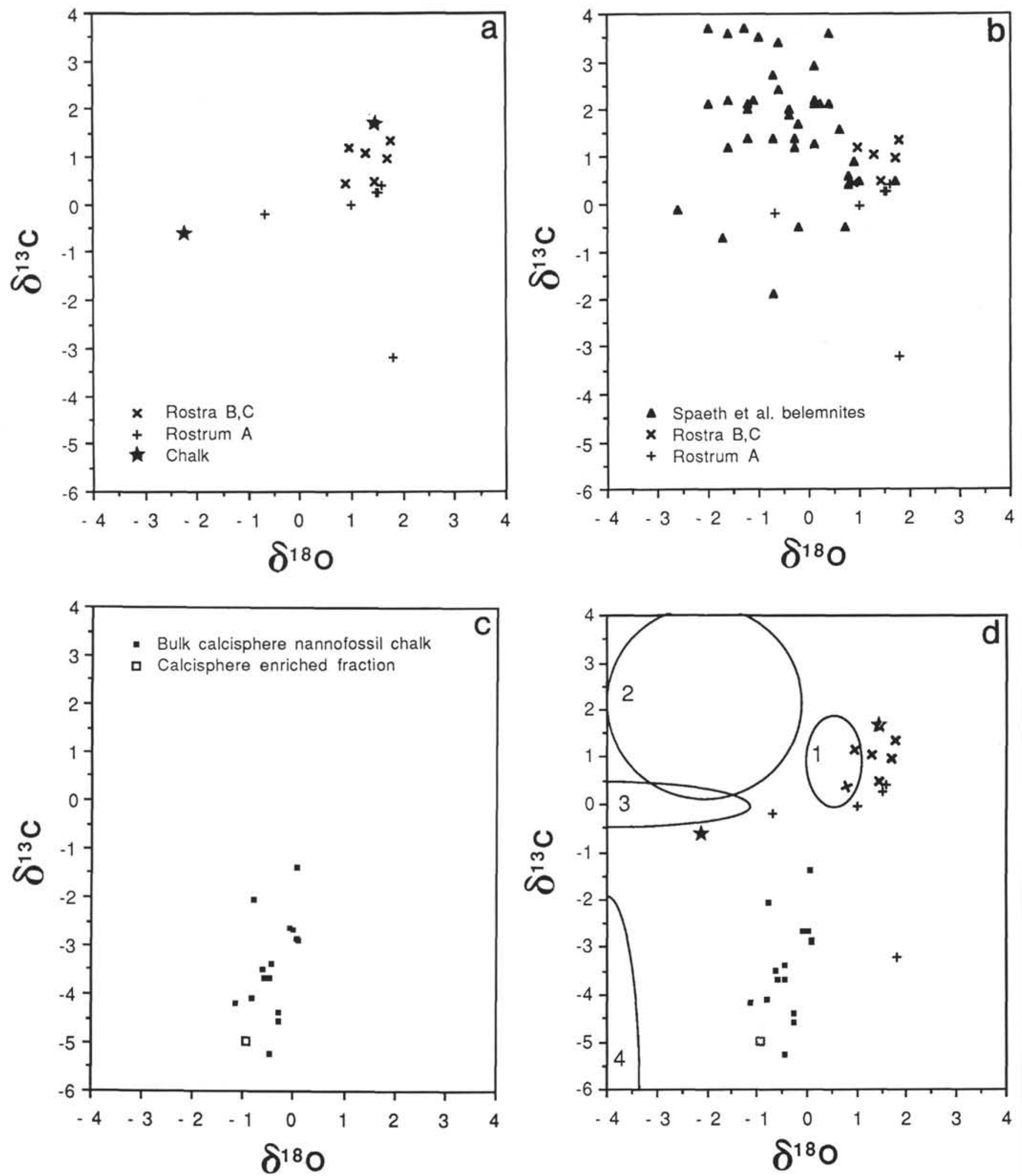

Figure 4. A. Carbon and oxygen isotopic measurements of belemnites and associated chalk lenses. B. Comparison of belemnite measurements from a) with data of Spaeth et al. (1971). C. Isotopic measurements of bulk samples of calcisphere nannofossil chalk. Open square is calcisphere-enriched fraction of Sample 122-761C-7R-1, 145-146 cm. D. Comparison of measured values with typical isotopic values of marine and non-marine sedimentary rocks (data from Hudson, 1977). Fields are (1) ooze, (2) chalk, (3) average marine limestone, and (4) average freshwater limestone. Symbols as in Fig. 4A-C. Raw data are compiled in Table 2. See text for discussion. 
occur in high abundances in pelagic sections near the Cenomanian-Turonian boundary, in an environment known to be unstable based on the absence of other taxa (Arthur et al., 1987). Perhaps these dinoflagellates took advantage of extremely productive conditions in a similar fashion to their modern counterparts, producing calcispheres as resting cysts when surface conditions became unstable. Bottjer et al. (1986) postulated that calcispheres were less tolerant of low-salinity conditions. However, the isotopic results of Arthur et al. (1986) indicate the contrary, because calcisphere-rich samples have lighter $\delta^{18} \mathrm{O}$ values, which, if interpreted in terms of salinity alone, would indicate fresher water.

Thoracosphaera heimii is a living dinoflagellate which produces a calcareous skeleton during its vegetative life stage (Tangen et al., 1982). However, it is not certain whether ancient thoracospheres are related to $T$. heimii as is most often inferred, or whether they are resting cysts as has been postulated by Fütterer (1977). Therefore, the specimens described here as thoracospheres may have a similar paleoenvironmental significance to calcispheres. Regardless of its taxonomic affinity, ancient Thoracosphaera was an opportunistic genus; it quickly filled the niche vacated by the extinction of calcareous nannoplankton species at the Cretaceous-Tertiary boundary (e.g., Thierstein, 1981).

Based on the absence of foraminifers and other normal marine faunal elements, it is clear that both calcispheres and thoracospheres thrived in unstable environments in the Early Cretaceous of the Wombat Plateau. Harsh conditions are also indicated by the low diversity of assemblages of these organisms. It is most likely that this instability was caused by fluctuating salinity and/or productivity.

Interpretation of most coccolith assemblage studies is difficult because there are few known species which can be directly associated with an individual paleoecologic parameter. In addition, changes in relative proportions of particular solution-resistant taxa can often be explained by preservational phenomena. Of all the taxa occurring in the sediments investigated, only a few have been cited as having paleoecological significance. The relative abundance of the solutionresistant form Watznaueria barnesae is often cited as an index of preservation (e.g., Roth and Bowdler, 1981), and more recently as an indicator of low fertility (Erba et al., 1989). Abundant Parhabdolithus asper has been used to indicate the occurrence of warmer water masses (Erba et al., 1989). The overall assemblage in diverse samples of calcisphere nannofossil chalk contains some dominantly Tethyan taxa (e.g., Speetonia colligata, Conusphaera mexicana subsp. mexicana) but shows a strong similarity to two previously described high-latitude Lower Cretaceous nannofloras. These floras include lower Aptian assemblages from DSDP Site 511 on the Falkland Plateau (Wise, 1983) and Valanginian assemblages from ODP Site 692 in the Weddell Sea (Mutterlose and Wise, 1990).

Common elements of floras from Sites 511, 692, and 761 include the high relative abundances of Watznaueria barnesae, W. ovata, Parhabdolithus embergeri, and Crucibiscutum salebrosum. All three sites were presumably situated in narrow, mid-high-latitude ocean basins at the time these assemblages formed. Restricted circulation, and resulting salinity or productivity extremes, is preferred as a paleoenvironmental explanation for these floral similarities, rather than comparable mid-high latitude. This explanation fits with the generally low diversity of assemblages and the presence of several Tethyan markers in Site 761.

The rare coccoliths observed in the belemnite sandstone unit are generally of poor preservation, which may explain the overall low diversity of assemblages. The great abundance of belemnites in this unit is significant. Belemnites may also have been opportunistic based on their enrichment in particular horizons in which other faunal elements are impoverished. The best example of this is the Cenomanian-Turonian boundary Plenus Bank in northwest Europe which is named after the low-diversity belemnite fauna composed predominantly of Actinocamax plenus (e.g., Jefferies, 1963).

\section{Implications of the Stable Isotopic Data}

Stable isotopic analyses of belemnites and bulk sediments are used to further constrain paleoenvironmental interpretations for these low-diversity faunal and floral assemblages.

\section{Belemnites}

There has been considerable discussion in the literature as to whether belemnite shells serve as reliable bases for paleotemperature analyses. Some authors believe belemnites to preserve their original isotopic signature and therefore have interpreted variations in terms of temperature and salinity (e.g., Urey et al., 1951; Lowenstam and Epstein, 1954; Mackenzie, 1988). Others (e.g., Spaeth et al., 1971; Veizer, 1974) have shown that the original mineralogy and porosity of belemnites has been changed during diagenesis and that this has affected their isotopic values. It is not possible to disregard the possibility that the isotopic values in the rostra analyzed have been affected by diagenetic processes, especially as it is clear that recrystallization has occurred in all three specimens. However, the data presented and discussed in the following allow paleoenvironmental interpretation.

All but two of the belemnite analyses are tightly clustered with $\delta^{18} \mathrm{O}$ between $0.90 \%$ and $1.79 \%(\mathrm{X}=1.41)$ and $\delta^{13} \mathrm{C}$ between $-0.20 \%$ and $1.34 \%$ o $(\bar{X}=0.57$ ) (Fig. 4A). Two belemnite samples have isotopic values outside this cluster. Both of these were taken from the outside of rostrum A yet are very different. One $(\mathrm{A}-5)$ has a lighter $\delta^{18} \mathrm{O}(-0.67 \%)$ and $\delta^{13} \mathrm{C}$ $(-0.20 \%)$; the other $(\mathrm{A}-1)$ has a normal $\delta^{18} \mathrm{O}(1.79 \%)$ and exceptionally light $\delta^{13} \mathrm{C}(-3.20 \%)$. One bulk sample analyzed from the sandstone unit $(122-761 \mathrm{C}-10 \mathrm{R}-2,22-23 \mathrm{~cm})$, composed almost entirely of bladey diagenetic calcite has a similar isotopic signature to the belemnites. A second sample (122$761 \mathrm{C}-10 \mathrm{R}-1,136-137 \mathrm{~cm}$ ), whose carbonate is entirely from coccoliths, has slightly lighter $\delta^{13} \mathrm{C}(-0.63 \%)$ and much lighter $\delta^{18} \mathrm{O}(-2.26 \%$ ) than the belemnites. This sample lies closer to the average field for marine limestone (Fig. 4D).

There does not appear to be a clear relationship between stable isotopic values of the belemnite rostra and preservation. All three rostra are calcitic (J. Compton, pers. comm., 1990), and this may have been the original mineralogy of these specimens (e.g., Dauphin, 1984). Detailed SEM observations of the three rostra indicate a variable amount of recrystallization (Pls. 6 and 7). Rostra B and C both possess concentric growth bands; however, the originally prismatic crystals which are radially oriented (Bandel, 1990) are largely overgrown or entirely recrystallized (Pl. 7, Figs. 5, 6). Rostrum A is considerably more porous; however, the degree of porosity generally decreases toward the center, indicating some recrystallization (Pl. 6, Figs. 3-5; Pl. 7, Figs. 1-4). The outer wall is highly porous. Specimen A gives similar oxygen isotopic values to $B$ and $C$, but generally lighter carbon isotopic values (Fig. 4A). This specimen has a diagenetically formed tube along the apical line (Pl. 6, Figs. 1, 2). The apical tube (analysis A-6) gives somewhat similar isotopic values to three analyses (A-2 to A-4) from the outer layer of the rostrum which appears to be at least partially composed of original calcite. This suggests that recrystallization of shell material to form the apical tube has not altered its isotopic values. An 
alternative is that all of the isotopic values measured have been altered by recrystallization.

The oxygen isotopic values obtained for the belemnites are slightly heavier than the typical range for these fossils as measured by several authors (e.g., Fig. 4B). Urey et al. (1951) measured $\delta^{18} \mathrm{O}$ on belemnites from the Upper Cretaceous of England and the southeastern U.S. ranging from $0.0 \%$ to $-1.4 \%$. Mackenzie (1988) analyzed numerous Campanian and Maestrichtian belemnites from Limburg (southern Netherlands) yielding ranges for $\delta^{18} \mathrm{O}$ of $-0.5 \% \circ$ to $1.2 \% \circ$ and $\delta^{13} \mathrm{C}$ of $0.0 \%$ to $3.0 \%$. Spaeth et al. (1971) made a detailed set of measurements on various parts of well-preserved Jurassic rostra and phragmocones giving values of $\delta^{18} \mathrm{O}$ of $1.7 \%$ to $-6.3 \%$. These authors showed that a considerable isotopic range existed in the different parts of any one specimen and advised against the use of one measurement for paleotemperature analysis. They suggested that the exceptionally light $\delta^{18} \mathrm{O}$ values measured in the aragonitic septa of the phragmocone may result from the addition of metabolic carbon dioxide. The two anomalous values obtained here from the outside of rostrum A may similarly be the result of addition of metabolic $\mathrm{CO}_{2}$ and not reflect the isotopic signature of seawater. This may also be the cause of the generally lighter $\delta^{13} \mathrm{C}$ analyses in rostrum $\mathrm{A}$.

All of these previously analyzed belemnites occur in sediments deposited in open marine conditions. The fact that the Hole $761 \mathrm{C}$ belemnite isotopic values are heavier in $\delta^{18} \mathrm{O}$ than apparently better preserved specimens of other investigations (e.g., Fig. 4B) argues against, but does not exclude the possibility of, diagenetic alteration of isotopic values as this generally results in more negative $\delta^{18} \mathrm{O}$ (Anderson and Arthur, 1983; Pratt, 1985). This is also suggested by the similar $\delta^{18} \mathrm{O}$ values of (1) well-preserved rostrum $A$ and less well-preserved rostra $B$ and $C$, and (2) the diagenetic apical tube and the outer parts of the rostrum in specimen A (Table 2).

The slightly heavier oxygen isotopic values of most of the analyses compared to other belemnites may result from the mid-high $\left(40^{\circ} \mathrm{S}\right)$ paleolatitude and associated lower temperatures of the Exmouth Plateau in the Early Cretaceous. The heavy belemnite oxygen isotopic values compared to the measurement on the one bulk sample composed entirely of coccoliths (Sample 122-761C-10R-1, 136-137 cm) confirms previous suggestions that the belemnites lived in colder, intermediate waters. This is supported by the observation that belemnites usually have heavier oxygen isotopic values than associated molluscs, brachiopods, and fine fraction (e.g., Urey et al., 1951; Lowenstam and Epstein, 1954). An oxygen isotopic difference of $3 \% 0-4 \%$ would be equivalent to a temperature difference of $12^{\circ}-16^{\circ} \mathrm{C}$ (Epstein et al., 1953), a reasonable thermal gradient between surface and intermediate waters. The same equations provide temperature estimates of $4^{\circ}-8^{\circ} \mathrm{C}$ for this intermediate water and $20^{\circ} \mathrm{C}$ for surface water based on an isotopic value for the water $(\delta w)$ of -1.2 , a typically quoted value for pre-glacial seawater (Shackleton and Kennett, 1975). These estimates also seem reasonable for Cretaceous oceanic temperatures.

Even though a paleoenvironmental interpretation is preferred, it is stressed that poorly understood vital effects in these belemnites may be largely responsible for the results obtained.

\section{Bulk Calcisphere Nannofossil Chalk}

The calcisphere nannofossil chalk is generally lighter in both $\delta^{18} \mathrm{O}$ and $\delta^{13} \mathrm{C}$, the former ranging from $0.08 \%$ to $-0.79 \%$ $(\mathrm{X}=-0.43)$ and the latter from -1.36 to $-5.23 \%$ ( $\bar{X}=$ -3.49 ) (Fig. 4C). Interpretation of the bulk fine fraction is difficult as individual particles may be very different isotopi- cally (e.g., Paull and Thierstein, 1987). Paull and Thierstein (1987) showed that Holocene samples with $>50 \%$ thoracospheres tend to have an average of $1 \%$ more negative $\delta^{13} \mathrm{C}$ than those composed of other nannofossil taxa. Calcispheres in the samples analyzed may have lighter $\delta^{13} \mathrm{C}$ than thoracospheres and coccoliths. Enrichment of calcispheres in Sample $122-761 \mathrm{C}-7 \mathrm{R}-1,145-146 \mathrm{~cm}$, led to a decrease in $\delta^{13} \mathrm{C}$ from -4.17 to $-4.97 \%$. Another sample with a high proportion of calcispheres (Sample 122-761C-8R-1, 30-31 cm) also yielded a light $\delta^{13} \mathrm{C}$ value of $-4.37 \%$. However, the lightest carbon $(-5.23 \%$ o $)$ was measured in Sample 122-761C-9R-1, 91-92 cm, dominated by thoracospheres. Comparison of relative abundances of different particles and the isotopic values of the samples does not reveal any clear vital effects with respect to oxygen isotopes.

Isotopic analyses of the calcisphere nannofossil chalk do not fall into the fields for marine calcareous ooze, chalk, or marine or freshwater limestones (Fig. 4D). Carbon isotopic values are slightly lighter than most marine limestones and lie in the range of freshwater limestones. Oxygen isotopic values are heavier than both marine and freshwater limestones by at least $1 \% o-2 \%$, and slightly heavier than most chalks. This may be because there is a shift toward more negative $\delta^{18} \mathrm{O}$ with increasing lithification due to the formation of isotopically light cement. Chalk samples from Hole $761 \mathrm{C}$ contain minor amounts of secondary calcite. In addition, carbon and oxygen isotopic values of the calcisphere nannofossil chalk may have been affected by the development of neomorphic calcite overgrowth on the calcispheres (Pls. 3 and 4). Although $\delta^{18} \mathrm{O}$ is similar to Holocene and Pleistocene nannofossil assemblages (Anderson and Steinmetz, 1981) and calcareous ooze (Fig. 4D), $\delta^{13} \mathrm{C}$ are $1 \%$ - $3 \%$ o lighter.

The light carbon isotopic values of the calcisphere nannofossil chalk are interpreted as resulting from upwelling of deep waters enriched in ${ }^{12} \mathrm{C}$. Heavy oxygen isotopic values with respect to typical chalk (Fig. 4D) are also consistent with upwelling of cool waters from depth. A $\delta^{18} \mathrm{O}$ value of $0 \%$ to $-1 \%$ would be equivalent to a temperature range of $12^{\circ}$ to $15^{\circ} \mathrm{C}$ given a $\delta w$ of -1.2 . This estimate seems reasonable for this mid-high paleolatitude location but would also be consistent with the occurrence of upwelling. Alternatively, these heavy oxygen values may have resulted from elevated salinities. A $1 \% 0-2 \%$ increase in $\delta^{18} \mathrm{O}$ would translate to an increase in salinity of $3 \%_{0}-10 \%$ based on standard equations (e.g., Berger, 1979). However, elevated salinities would not be expected at a mid-high paleolatitude. The anomalous isotopic values of the various fine-fraction fossil particles could also be a result of strong vital effects.

\section{Depositional Environment}

The sandstone in which the belemnites are found is composed largely of quartz and lithic fragments with minor amounts of clay. Such petrography indicates the presence of active bottom currents. This sandstone was transgressive, deposited as the ocean flooded the newly rifted basin. The lithic fragments are probably Triassic in age (von Rad et al., this volume). The lack of clastic material in the calcisphere nannofossil chalk is perplexing. One would expect a significant clastic supply in a youthful ocean basin from the newly elevated margins. However, the major non-carbonate component in this unit is clay and this seems similar mineralogically to the bentonite horizons that are found in this unit. Bentonites at this site and Site 765 in the Argo Abyssal Plain indicate active volcanism at this time in this part of Tethys (von Rad and Thurow, this volume).

The preferred hypothesis for the origin of these unusual deposits is as follows. Rising relative sea level concurrent with 
rift-related subsidence led to the deposition of the transgressive sandstone. The narrow, east-west ocean basin was highly productive partly because of its orientation (e.g., Cook and McElhinny, 1979) and partly as a result of fluvial input. Belemnites took advantage of this productivity living, for the most part, in the deepest part of the water column. Continued rise in relative sea level, and perhaps further increased productivity, led to the introduction of new opportunistic, pelagic organisms into the basin, including calcareous dinoflagellates, which may have secreted thoracospheres in their vegetative stages, and calcispheres, and maybe thoracospheres, as resting cysts during particularly unstable periods. Radiolarians were also able to take advantage of high nutrient levels. Low-diversity coccolith assemblages in both units testify to the absence of true open ocean conditions. Upwelling of cool waters also led to the somewhat heavy oxygen isotopic values measured in the belemnites and bulk calcisphere nannofossil chalk. Light carbon isotopic values in the calcisphere nannofossil chalk are also consistent with upwelling. I wish to stress that while this paleoenvironmental interpretation is consistent with the isotopic data, it is not possible to rule out the alternative explanation that the isotopic values result from poorly understood vital effects in these unusual organisms.

\section{CONCLUSIONS}

1. A sedimentary sequence documenting the earliest history of the proto-Indian Ocean was drilled at Site 761 on the Wombat Plateau, northwest Australia. Directly above the post-rift unconformity, two sedimentary units were recovered which reflected deposition in the earliest oceanic environments.

2. The lower unit, composed of sandstone, contains abundant belemnites, and a few lenses composed of low-diversity coccolith assemblages. The second unit, composed of chalk, contains abundant calcispheres, thoracospheres, low-diversity coccolith assemblages, and minor radiolarians.

3. The organisms that produced calcispheres, thoracospheres, and belemnites are thought to be opportunistic, and their abundance, as well as the absence of normal marine faunal elements, shows that they occupied an unstable environment which occurred in this young ocean basin.

4. Stable isotopic data for oxygen and carbon for the two units fall into almost separate fields. Heavy $\delta^{18} \mathrm{O}$ values for the belemnites do not appear to have been affected by recrystallization, and are thought to result from the deep habitat of these organisms or from strong vital effects. Coccolith $\delta^{18} \mathrm{O}$ values from this unit are lighter. The light $\delta^{13} \mathrm{C}$ values for the calcisphere nannofossil chalk are thought to result from upwelling. Heavy $\delta^{18} \mathrm{O}$ values for this unit are thought to result from upwelling or strong vital effects.

5. Combination of assemblage and isotopic data are consistent with this early ocean basin being highly productive, either by upwelling and/or by input of nutrient-rich waters from nearby land areas.

\section{ACKNOWLEDGMENTS}

The author acknowledges helpful discussions with $\mathbf{M}$. Arthur, W. Balch, C. Blome, J. Carter, J. Compton, H. Jenkyns, S. O'Connell, C. Paull, P. Swart, and U. von Rad. I am grateful to J. Compton, B. Haq, H. Keupp, S. Margolis, J, Mutterlose, C. Paull, and C. Spaeth for reviews of a previous manuscript. I thank P. Swart (University of Miami) and J. Compton (University of South Florida) for providing isotopic and XRD analyses, respectively, and $\mathrm{H}$. Keupp for taxonomic identification of calcispheres. I thank N. Romer and J. Leal for assistance with SEM analysis, and J. Arfstrom and C.
Botelho for laboratory and darkroom support. Research funded by USSAC (PO\#20278).

\section{REFERENCES}

Anderson, T. F., and Arthur, M. A., 1983. Stable isotopes of oxygen and carbon and their application to sedimentologic and paleoenvironmental problems. SEPM Short Course, 10:1-151.

Anderson, T. F., and Steinmetz, J. C., 1981. Isotopic and biostratigraphic records of calcareous nannofossils in a Pleistocene core. Nature, 294:741-744.

Arthur, M. A., and Research On Cretaceous Cycles Group, 1986. Rhythmic bedding in Upper Cretaceous pelagic carbonate sequences: varying sedimentary response to climatic forcing. Geology, 14:153-156.

Arthur, M. A., Schlanger, S. O., and Jenkyns, H. C., 1987. The Cenomanian-Turonian Oceanic Anoxic Event, II. Palaeoceanographic controls on organic-matter production and preservation. In Brooks, J., and Fleet, A. J. (Eds.), Marine Petroleum Source Rocks. Geol. Soc. London Spec. Publ., 26:401-420.

Bandel, K., 1990. Cephalopod shell structure and general mechanisms of shell formation. In Carter, J. G. (Ed.), Skeletal Biomineralization: Patterns, Processes and Evolutionary Trends (Vol. 1): New York (Van Nostrand Reinhold), 97-116.

Bandel, K., and Spaeth, S., 1988. Structural differences in the ontogeny of some belemnite rostra. In Wiedmann, J., and Kullmann, J. (Eds.), Cephalopods-Present and Past: Stuttgart (Schweiz Verlag), 247271.

Berger, W. H., 1979. Stable isotopes in foraminifera. Soc. Econ. Paleontol. Mineral., Short Course, 6:156-198.

Bolli, H. M., 1974. Jurassic and Cretaceous Calcisphaerulidae from DSDP Leg 27, Eastern Indian Ocean. In Veevers, J. J., Heirtzler, J. R., et al., Init. Repts. DSDP, 27: Washington (U.S. Govt. Printing Office), 843-907.

Bottjer, D. J., Arthur, M. A., Dean, W. E., Hattin, D. E., and Savrda, C. E., 1986. Rhythmic bedding produced in Cretaceous pelagic carbonate environments: sensitive recorders of climatic cycles. Paleoceanography, 1:467-481.

Bralower, T. J., Monechi, S., and Thierstein, H. R., 1989. Calcareous nannofossil zonation of the Jurassic-Cretaceous boundary interval and correlation with the geomagnetic polarity timescale. Mar. Micropaleontol., 14:153-235.

Cook, P. J., and McElhinny, M. W., 1979. A reevaluation of the spatial and temporal distribution of sedimentary phosphate deposits in the light of plate tectonics. Econ. Geol., 74:315-330

Dauphin, Y., 1984. Apport de l'analyse microstucturale au problème de l'homologie des tissus coquilliers chez les Céphalopodes. Ann. Paléontol., 70:87-113.

Dodd, J. R., and Stanton, R. J., 1975. Paleosalinities within a Pliocene bay, Kettleman Hills, California: A study of the resolving power of isotopic and faunal techniques. Geol. Soc. Am. Bull., 86:51-64.

Dudley, W. C., Blackwelder, P. L., Brand, L. E., and Duplessey, J. C., 1986. Stable isotopic composition of coccoliths. Mar. Micropaleontol., 10:1-8.

Dudley, W. C., and Goodney, D. E., 1979. Oxygen isotopic content of coccoliths grown in culture. Deep-Sea Res. Part A, 26:495-503.

Epstein, S., Buchsbaum, R., Lowenstam, H. A., and Urey, H. C., 1953. Revised carbonate-water isotopic scale. Geol. Soc. Am. Bull., 64:1315-1325.

Erba, E., Guasti, G., and Castradori, D., 1989. Calcareous nannofossils record fertility and temperature cycles: evidence from the Albian Gault Clay Formation. INA Newsl., 11:57-58.

Fischer, A. G., and Arthur, M. A., 1977. Secular variations in the pelagic realm. In Cook, H. E., and Enos, P. (Eds.), Deep Water Carbonate Environments. Spec. Publ. Soc. Econ. Paleontol. Mineral., 25:19-50.

Fütterer, D., 1977. Distribution of calcareous dinoflagellates in Cenozoic sediments of site 366, eastern North Atlantic. In Lancelot, Y., Seibold, E., et al., Init. Repts. DSDP, 41: Washington (U.S. Govt. Printing Office), 709-737.

Geary, D. H., Rich, J., Valley, J. W., and Baker, K., 1989. Stable isotopic evidence of salinity change: influence on the evolution of melanopsid gastropods in the late Miocene Pannonian basin. Geology, 17:981-985. 


\section{T. J. BRALOWER}

Haq, B. U., von Rad, U., O'Connell, S., et al., 1990. Proc. ODP, Init. Repts., 122: College Station, TX (Ocean Drilling Program).

Hudson, J. D., 1977. Stable isotopes and limestone lithification. $J$. Geol. Soc. London, 133:637-660.

Jefferies, R.P.S., 1963. The stratigraphy of the Actinocamax plenus subzone (Turonian) in the Anglo Paris Basin. Proc. Geol. Assoc., $74: 1-33$.

Keupp, H., 1979. Lower Cretaceous Calcisphaerulidae and their relationship to calcareous dinoflagellate cysts. Bull. Cent. Rech. Explor.-Prod. Elf-Aquitaine, 3:651-663.

Lins, T. W., Johnson, F. E., Keady, D. M., and Russell, E. E., 1977. The arcola limestone-a Cretaceous calcisphere wackestone and grainstone. Geol. Soc. Am. Abstr. Programs, 9:159.

Lowenstam, H. A., and Epstein, S., 1954. Paleotemperatures of the post-Aptian Cretaceous as determined by the oxygen isotope method. J. Geol., 62:207-248.

Mackenzie, G. J., 1988. Palaeoenvironmental interpretation of the upper Campanian and Maastrichtian sediments of S. Limburg: an integrated geochemical, palaeontological and sedimentological study [Unpubl. Ph.D. Thesis]. Univ. London.

Mutterlose, J., in press. Early Cretaceous belemnites from the East Indian Ocean and their paleobiogeographic implications. In Gradstein, F. M., Ludden, J. N., et al., Proc. ODP, Sci. Results, 123: College Station, TX (Ocean Drilling Program).

Mutterlose, J., and Wise, S. W., Jr., 1990. Lower Cretaceous nannofossil biostratigraphy of ODP Leg 113 Holes 692B and 693A, continental slope off East Antarctica, Weddell Sea. In Barker, P. F., Kennett, J. P., et al., Proc. ODP, Sci. Results, 113: College Station, TX (Ocean Drilling Program), 325-351.

Paull, C. K., Hills, S. J., and Thierstein, H. R., 1988. Progressive dissolution of fine carbonate particles in pelagic sediments. Mar. Geol., 81:27-40.

Paull, C. K., and Thierstein, H. R., 1987. Stable isotopic fractionation among particles in Quaternary coccolith-sized deep-sea sediments. Paleoceanography, 2:423-429.

Pratt, L. J., 1985. Isotopic studies of organic matter and carbonate in rocks of the Greenhorn Marine Cycle. In Pratt, L. M., Kauffman, E. G., and Zelt, F. B. (Eds.), Fine-grained Deposits and Biofacies of the Cretaceous Western Interior Seaway: Evidence of Cyclic Sedimentary Processes. Field Trip Guidebook, Soc. Econ. Paleontol. Mineral., 4:38-48.

Roth, P. R., and Bowdler, J. L., 1981. Middle Cretaceous calcareous nannoplankton biogeography and oceanography of the Atlantic Ocean. In Warme, J. E., Douglas, R. G., and Winterer, E. L.
(Eds.), The Deep Sea Drilling Project: A Decade of Progress. Spec. Publ. Soc. Econ. Paleontol. Mineral., 32:355-394.

Sanfilippo, A., and Riedel, W. R., 1985. Cretaceous radiolaria. In Bolli, H. M., Saunders, J. B., and Perch-Nielsen, K. (Eds.), Plankton Stratigraphy: Cambridge (Cambridge Univ. Press), 573 630.

Shackleton, N. J., and Kennett, J. P., 1975. Paleotemperature history of the Cenozoic and the initiation of Antarctic glaciation: oxygen and carbon isotope analyses in DSDP Sites 277,279 and 281. In Kennett, J. P., Houtz, R. E., et al., Init. Repts. DSDP, 29: Washington (U.S. Govt. Printing Office), 743-755.

Spaeth, C., Hoefs, J., and Vetter, U., 1971. Some aspects of isotopic composition of belemnites and related paleotemperatures. Bull. Geol. Soc. Am., 82:3139-3150.

Tangen, K., Brand, L. E., Blackwelder, P. L., and Guillard, R.R.L., 1982. Thoracosphaera heimii (Lohmann) Kamptner is a dinophyte: observations on its morphology and life cycle. Mar. Micropaleontol., 7:193-212.

Thierstein, H. R., 1981. Late Cretaceous nannoplankton and the change at the Cretaceous-Tertiary boundary. In Warme, J. E., Douglas, R. G., and Winterer, E. L. (Eds.), The Deep Sea Drilling Project: A Decade of Progress: Spec. Publ. Soc. Econ. Paleontol. Mineral., 32:355-394.

Urey, H. C., Lowenstam, H. A., Epstein, S., McKinney, C. R., 1951. Measurement of paleotemperatures and temperatures of the Upper Cretaceous of England, Denmark and the southeastern United States. Geol. Soc. Am. Bull., 62:399-416.

Veizer, J., 1974. Chemical diagenesis of belemnite shells and possible consequences for paleotemperature determinations. Neues Jahrb. Geol. Palaeontol. Abh., 147:91-111.

Wall, D., Guillard, R.R.L., Dale, B., Swift, E., and Watabe, N., 1970. Calcitic resting cysts in Peridinium trochoidium (Stein) Lemmermann, an autotrophic marine dinoflagellate. Phycologia, 9:151156.

Wise, S. W., Jr., 1983. Mesozoic and Cenozoic calcareous nannofossils recovered by Deep Sea Drilling Project Leg 71 in the Falkland Plateau region, Southwest Atlantic Ocean. In Ludwig, W. J., Krasheninnikov, V. A., et al., Init. Repts. DSDP, 71: Washington (U.S. Govt. Printing Office), 481-550.

Date of initial receipt: 3 May 1990

Date of acceptance: 27 December 1990

Ms 122B-155 

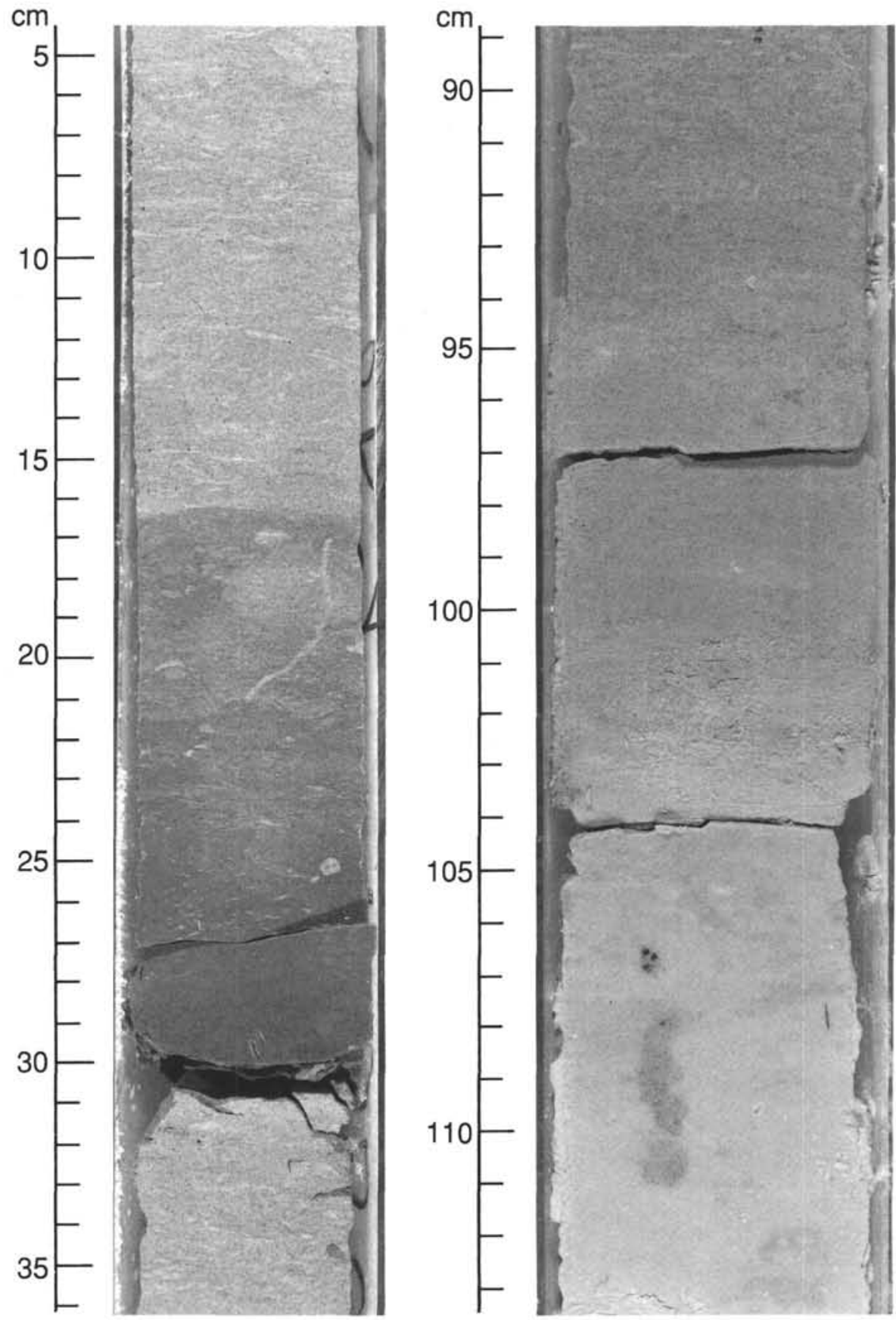

Plate 1. Lithology of calcisphere nannofossil chalk unit. Photograph at left is from Section 122-761C-8R-2, 4-36 cm, and shows color variations from light to dark yellowish brown in the calcisphere nannofossil chalk. Photograph at right is from Section 122-761C-8R-1, 89-113 cm, and illustrates the gradual contact between the calcisphere nannofossil chalk at top and waxy bentonite below. 

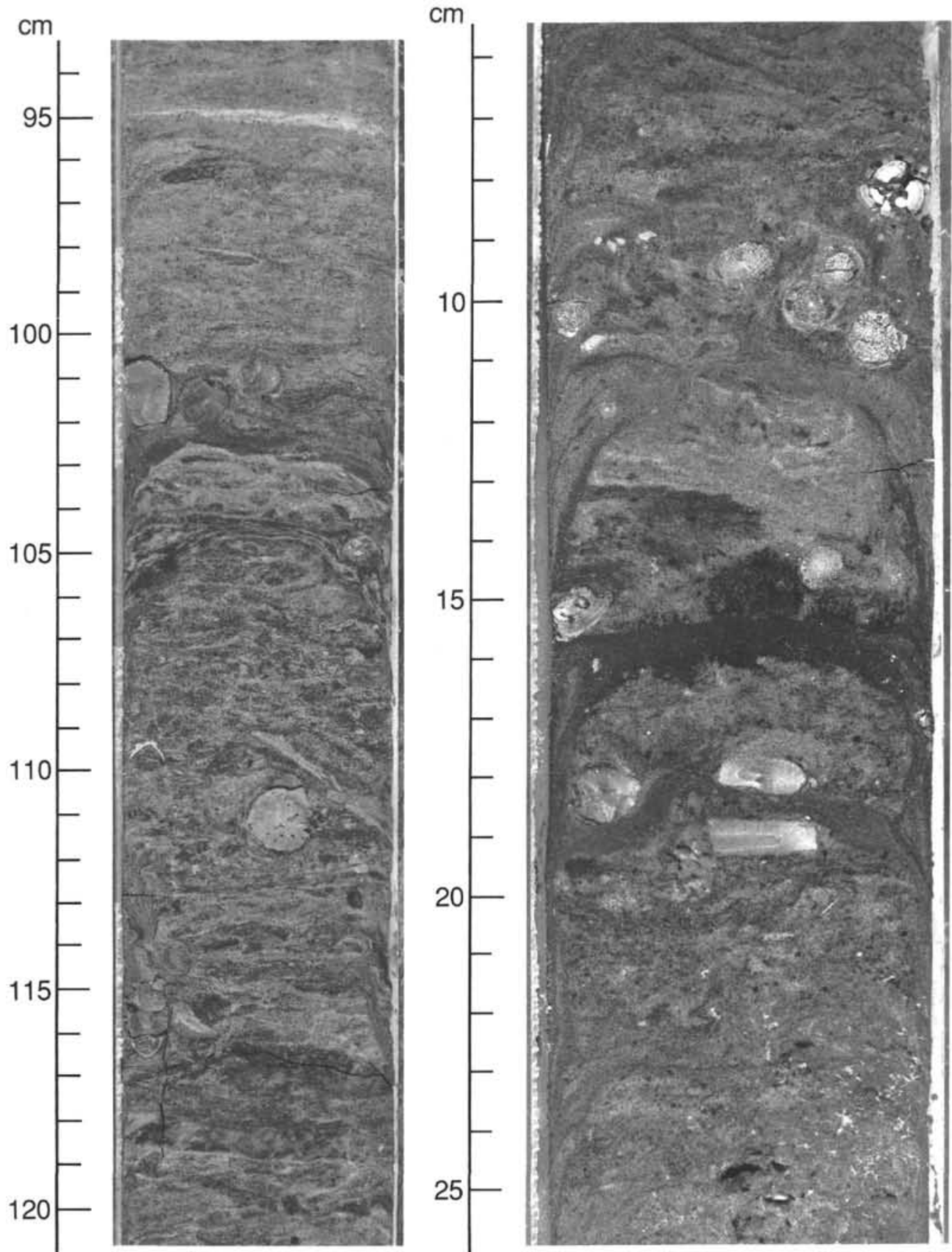

Plate 2. Lithology of belemnite sand unit. Photograph at left is from Section 122-761C-10R-1, 93-121 cm, and shows mottled appearance of lithology. Note presence of chalk lens at $95 \mathrm{~cm}$. Photograph at right is from Section 122-761B-30X-2, 6-26 cm, and shows enrichments of belemnite rostra in this unit. 

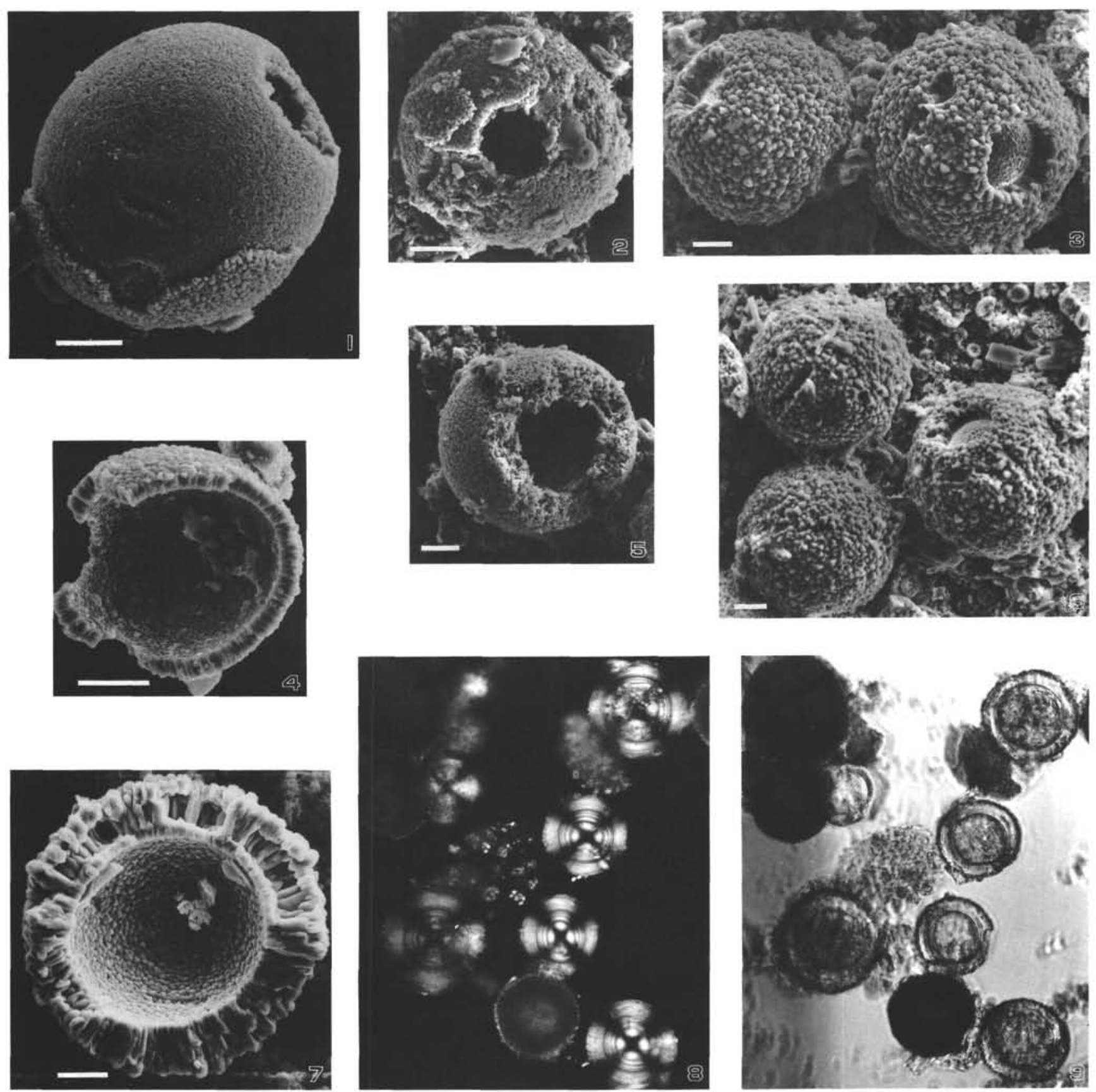

Plate 3. Micrographs of calcispheres. 1, 2, 5. Scanning electron micrographs of Obliquipithonella multistrata (Pflaumann and Krasheninnikov). 3, 4, 7. Scanning electron micrographs of Orthopithonella cf. deflandrei (Kamptner). 6. Scanning electron micrograph of three specimens of Orthopithonella cf. deflandrei (Kamptner) illustrating density of these forms in calcisphere nannofossil chalk. Several coccoliths can be seen for scale. 8. Cross-polarized light microscopic view of calcispheres. 9. Phase contrast light microscopic view of calcispheres. Specimens shown in Figures 1, 4, 8, and 9 are from Sample 122-761C-7R-1, 145-146 cm. All other specimens are from Sample $122-761 \mathrm{C}-8 \mathrm{R}-1,30-31 \mathrm{~cm}$. White scale bar represents $10 \mu \mathrm{m}$. Magnification of Figures 8 and 9 is $400 \times$. 


\section{T. J. BRALOWER}
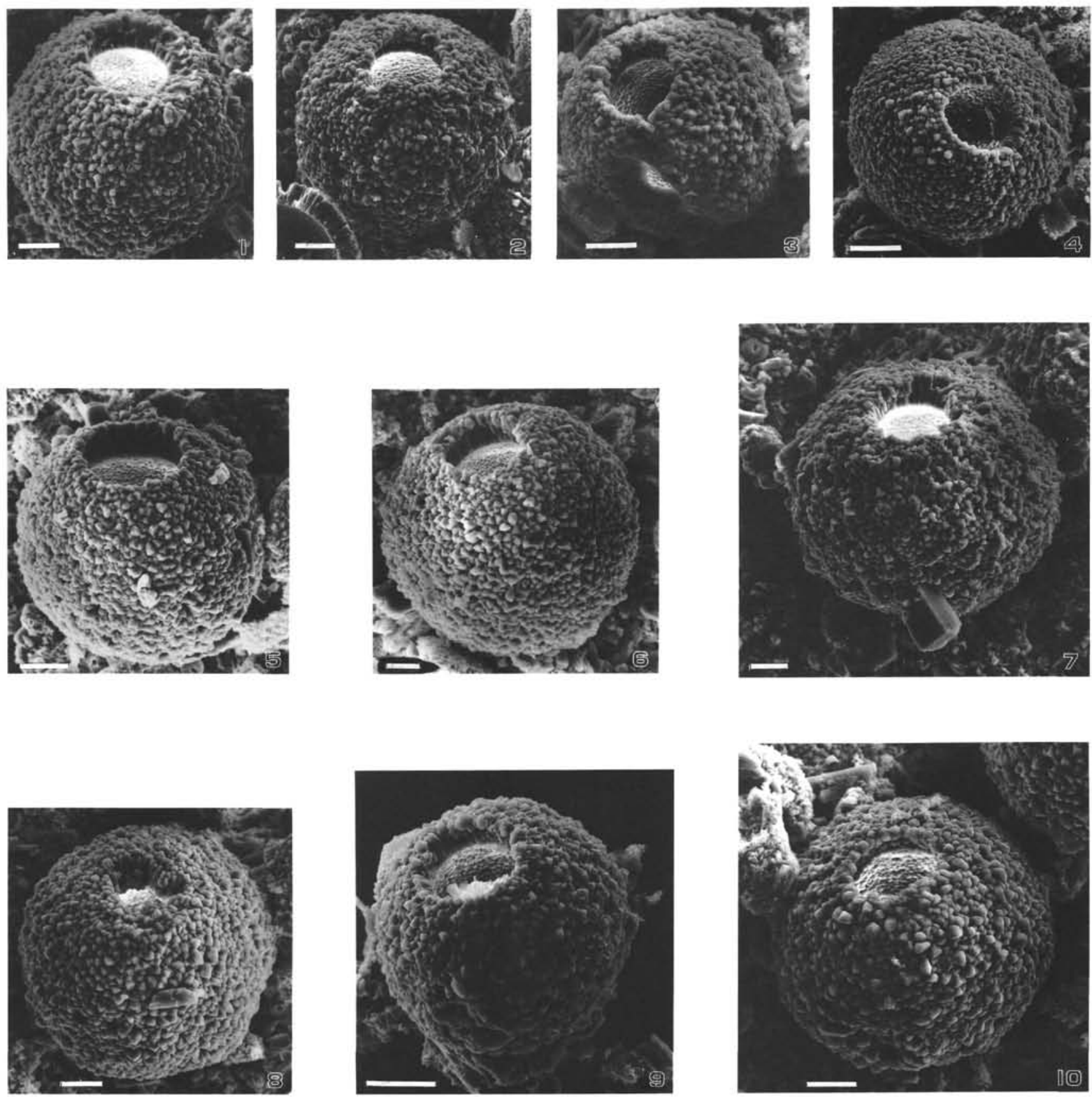

Plate 4. Scanning electron micrographs of calcispheres. 1-10. Orthopithonella cf. deflandrei (Kamptner). All specimens are from Sample 122-761C-8R-1, 30-31 cm. White scale bar represents $10 \mu \mathrm{m}$. 

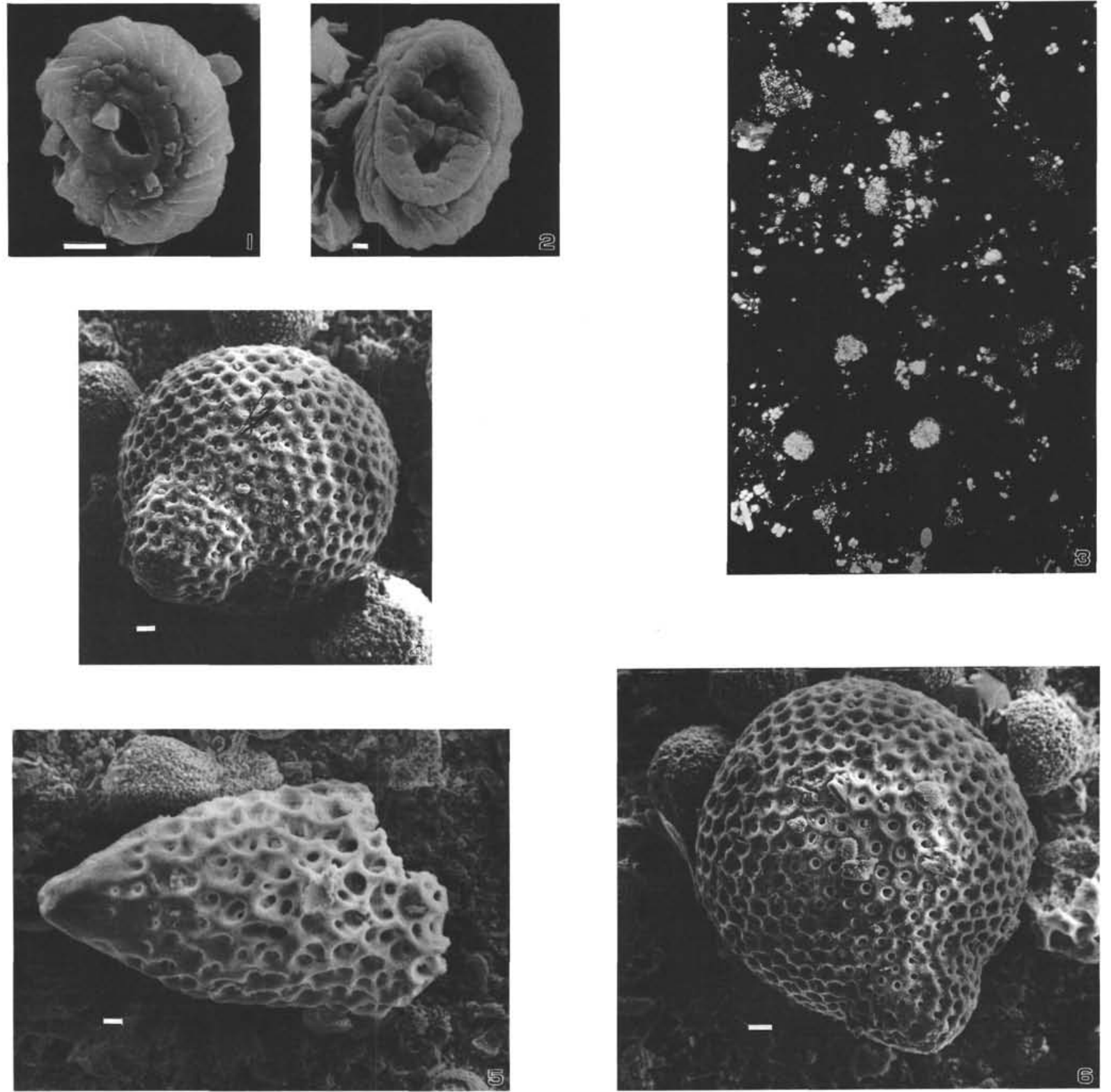

Plate 5. Micrographs of nannofossils and radiolarians. 1. Scanning electron micrograph of Watznaueria ovata, Sample 122-761C-7R-1, 145-146 $\mathrm{cm}$. 2. Scanning electron micrograph of Parhabdolithus embergeri, Sample 122-761C-7R-1, 145-146 cm. 3. Light microscopic view of thoracospheres and coccoliths. Sample 122-761C-9R-1, 91-92 cm. 4, 5, 6. Selected radiolarians. Sample 122-761C-8R-1, 30-31 cm. Figures 4 and 6 are Cryptamphorella conara (Foreman). White scale bars in Figures 1 and 2 represent $1 \mu \mathrm{m}$. White scale bars in Figures 4-6 represent $10 \mu \mathrm{m}$. Magnification of Figure 3 is $400 \times$. 

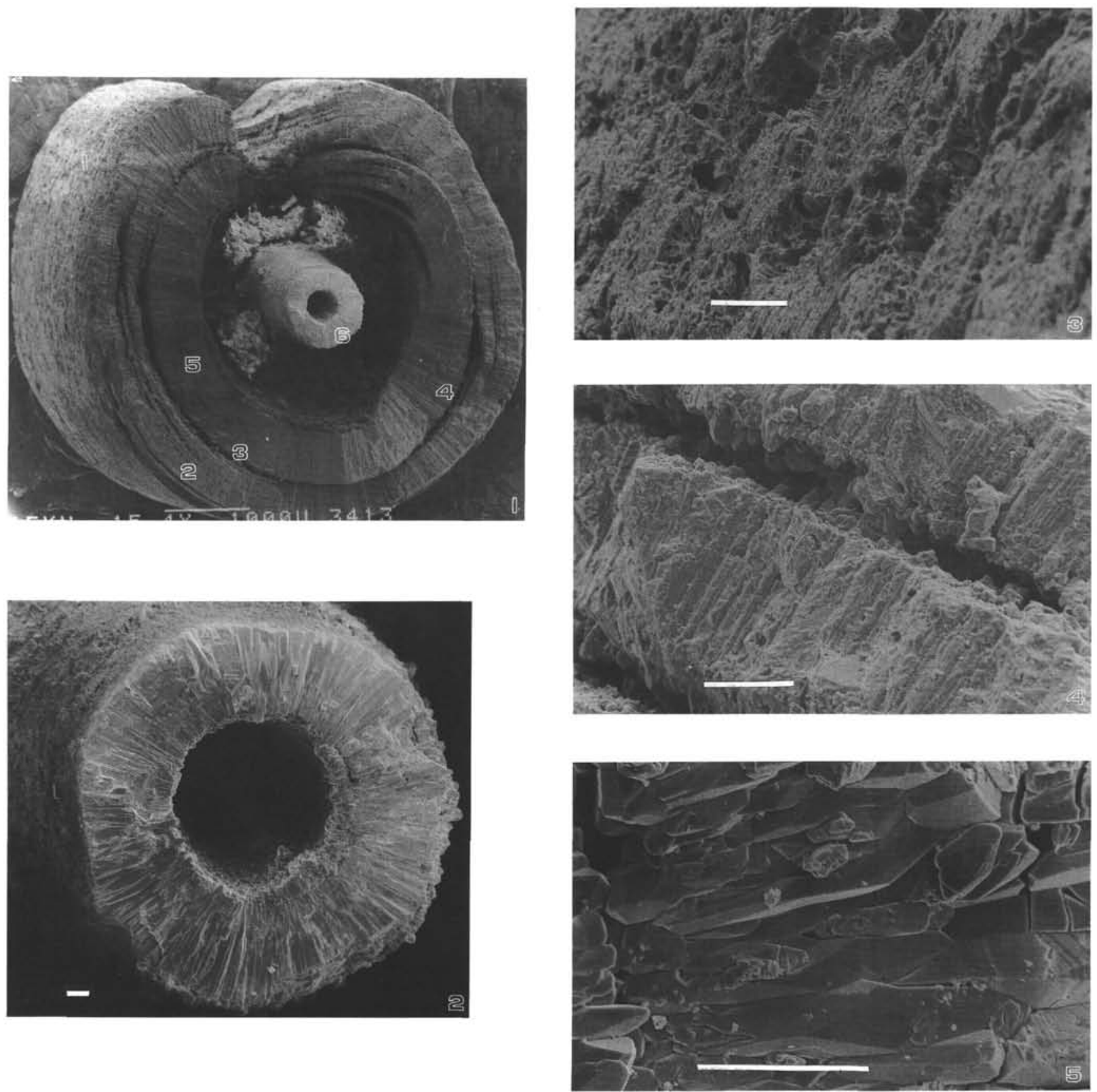

Plate 6. Scanning electron micrographs of belemnite rostrum A. 1. Cross-section of belemnite rostrum specimen A showing outer and inner layers and diagenetic apical tube. Numbers indicate location of samples taken for isotopes (see Table 2). Scale bar at bottom center is $1000 \mu \mathrm{m}$. 2. Cross-section of apical tube of belemnite specimen A. 3. Porous outer surface of belemnite specimen A. 4. View of outer layer showing concentric growth bands. 5. Detailed crystallography of apical tube from Figure 2. White scale bars in Figures $2-5$ are $50 \mu \mathrm{m}$. 

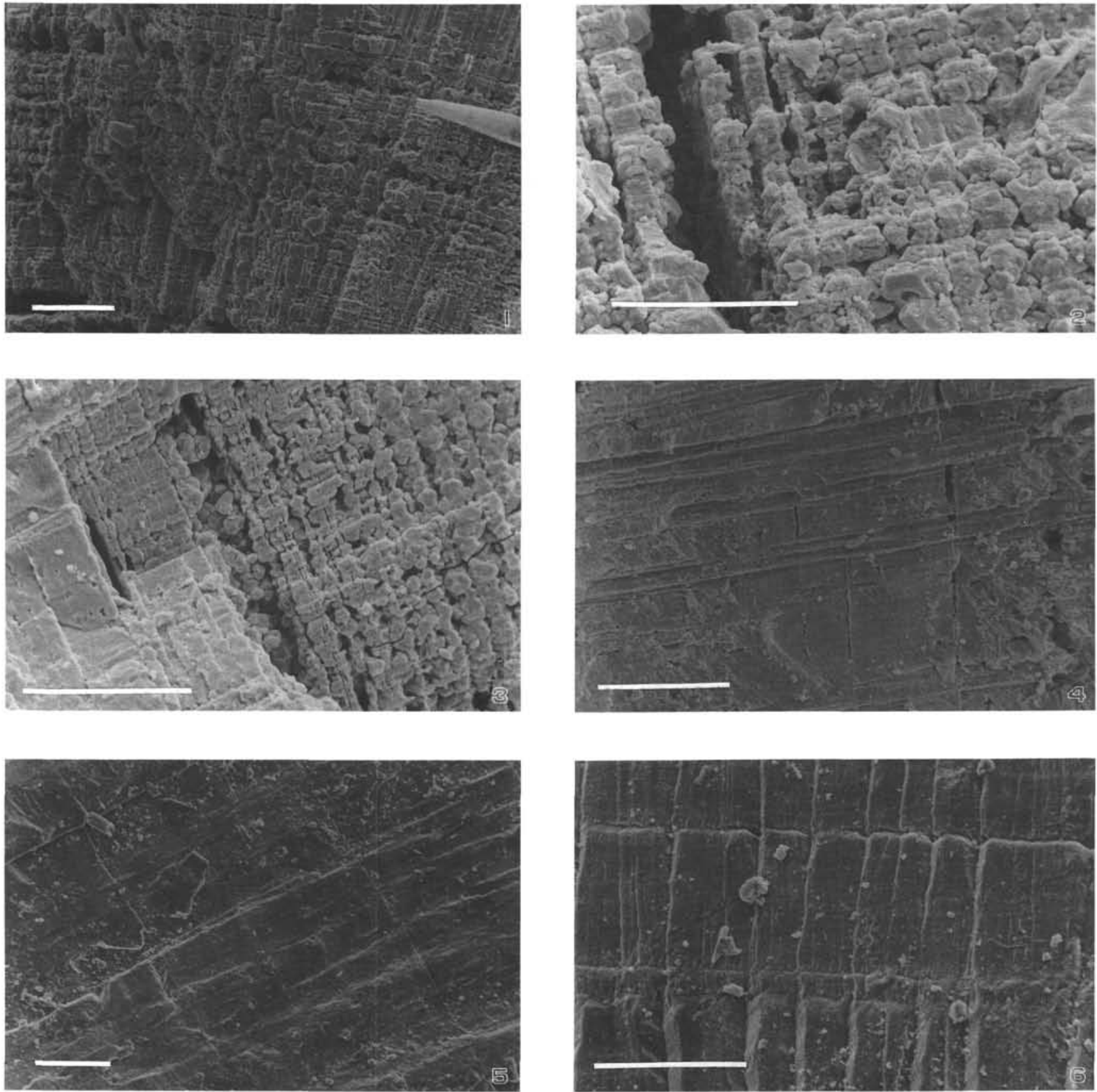

Plate 7. Scanning electron micrographs of belemnite rostra. 1. Detailed crystallography of outer layer of specimen A showing concentric growth bands and high degree of porosity. 2. Detailed crystallography of outer layer of specimen A showing concentric growth bands and high degree of porosity. 3. Outer layer showing decreasing porosity from outside (top right) toward inside (bottom left). 4. Low porosity of inside layer of specimen A. 5. Cross-section of rostrum specimen B. Faint concentric growth lines trend from top left to bottom right. 6. Cross-section of rostrum specimen B. Growth lines trend horizontally. Overgrown radial elements are aligned vertically. White scale bars represent $50 \mu \mathrm{m}$. 